\title{
$X: 153597467-153570672$
}

National Cancer Institute

\section{Source}

National Cancer Institute. X: 153597467-153570672. NCI Thesaurus. Code C45157.

Physical location of MPP1_Gene 